\title{
Anode Processes Malfunctions Causes. An Overview
}

\author{
Yuri G. Mikhaleva, Peter V. Polyakov*a, \\ Andrey S. Yasinskiya, Sergey G. Shahraia, \\ Aleksandr I. Bezrukikh ${ }^{a}$ and Andrey V. Zavadyak ${ }^{b}$ \\ ${ }^{a}$ Siberian Federal University \\ 79 Svobodny, Krasnoyarsk, 660041, Russia \\ ${ }^{b}$ «RUSAL ETC» LTD \\ 37/1 Pogranichnikov Str., Krasnoyarsk, 660111, Russia
}

Received 02.04.2017, received in revised form 29.04.2017, accepted 13.06.2017

One of the most common anodes malfunctions appearing after its set up is uneven anode's profile relief modification and protrusion formation, called "spikes", "mushrooms" "deformations" and "cones". Spikes can provide short circuits between anode and cathode, increase current fluctuations, carbon dust volume and noise. Another kind of anodes malfunctions is cracking due to thermal shock, which strikes "cold" anode during its setup. Pieces, formed as a result, fall into bath, make a technological malfunction, increase carbon consumption and make cell operating more difficult. One of the dangers of spikes formation is decrease of current efficiency and aluminium production economical and technical indices. An overview of Russian and foreign author's anodes malfunctions causes researches are presented in the paper.

Keywords: anode, malfunction, spike, carbon dust, current efficiency, bath.

Citation: Mikhalev Yu.G., Polyakov P.V., Yasinskiy A.S., Shahrai S.G., Bezrukikh A.I., Zavadyak A.V. Anode processes malfunctions causes. An overview, J. Sib. Fed. Univ. Eng. technol., 2017, 10(5), 593-606. DOI: 10.17516/1999-494X-2017-105-593-606.

(c) Siberian Federal University. All rights reserved

* Corresponding author E-mail address: y.mihalev@bk.ru, p.v.polyakov@mail.ru 


\title{
Причины технологических нарушений
}

\section{при анодных процессах. Обзор исследований российских и зарубежных экспериментаторов}

\author{
Ю.Г. Михалев ${ }^{\mathrm{a}}$ П.В.Поляков ${ }^{\mathrm{a}}$, А.С.Ясинский ${ }^{\mathrm{a}}$ \\ С.Г. Шахрай \\ ${ }^{a}$ Сибирский федеральный университет \\ Россия, 660041, Красноярск, пр. Свободный, 79

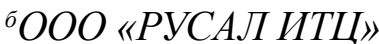

Россия, 660111, Красноярск, ул. Пограничников, 37/1

Одним из наиболее типичных видов технологических расстройств в анодах после их установки в электролизер является неравномерное изменение рельефа подошвы анода и образование на ней выступов, называемых в зарубежной технической литературе шипами, грибами, деформациями, в российской - конусами. Конусы могут вызвать короткое замыкание анода и катода, увеличить флуктуации тока, выход угольной пены, уровень шумов. Другой вид технологических расстройств в анодах-образование в них трещин вследствие теплового удара (термошока), который испытывает холодный анод при установке в расплав. Образовавшиеся в результате растрескивания куски анода попадают в электролит, нарушая технологический режим электролизера, увеличивая расход углерода и существенно осложняя обслуживание электролизера. Одна из основных опасностей образования конусов и растрескивания анода значительное снижение выхода по току и технико-экономических показателей производства алюминия. В настоящей статье представлен обзор исследований российских и зарубежных экспериментаторов, посвященных изучению причин технологических расстройств в анодах.

Ключевые слова: анод, нарушение, конус, угольная пена, выход по току, электролит.

\section{Причины возникновения технологических нарушений в анодах}

Одной из возможных причин изменения рельефа подошвы анода - образование и накопление угольных частиц, так называемой угольной пены, в электролите.

Согласно [1] источниками угольной пены в электролите являются:

- анодные блоки вследствие большей реакционной способности кокса из пека связующего и его селективного окисления с последующим осыпанием частиц кокса-наполнителя в расплав;

- износ углеродистой подины, вклад которой составляет от 0,5 до 1 кг углеродных частиц на 1 т алюминия;

- углеродистая масса, использующаяся для защиты ниппелей от окисления. Она дает от 0,5 до 6 кг углерода на 1 т алюминия (на российских заводах не применяется);

- материал укрытия анода, который содержит до 5 мас. \% углерода;

- углерод во вторичном глиноземе, содержание которого колеблется от 0,15 до 0,5 мас. $\%$.

Основная причина увеличения содержания углерода во вторичном глиноземе согласно [2, 3] вызвана переходом на сухую газоочистку, при которой увеличился выход и возросло количество конусов на анодах, что снизило выход по току в среднем на 1,6 \%. Кроме этого, увеличились трудозатраты на снятие угольной пены, на выявление и удаление конусов. 
В современных мощных электролизёрах, в которых используется точечное питание, аноды хорошо укрыты и частота анодных эффектов мала, следует ожидать большего накопления угольной пены. Принимая во внимание физические свойства углерода, можно ожидать сегрегации частиц угольной пены таким образом, что крупные частицы будут собираться у поверхности электролита, а мелкие - распределяться в объеме. Но при смене анодов, когда пена скапливается в «лузе», крупные частицы могут уходить вглубь электролита на 2 см. В среднем, по данным разных авторов, в электролите содержится от 1 до 5 мас. \% угольных частиц.

Большое количество угольной пены в электролите приводит к изменению свойств электролита и к различным технологическим нарушениям, которые включают:

- более медленный нагрев нового анода, вследствие чего для выравнивания силы тока по анодам требуется большее время;

- необходимость уменьшения расстояния между анодным массивом и алюминием (МПР) при заданной уставке по напряжению из-за неконтролируемого увеличения электросопротивления электролита;

- увеличение коэффициента динамической вязкости электролита;

- уменьшение скорости растворения и распределения глинозема в объеме, так как угольная пена препятствует свободному распространению глинозема;

- короткие замыкания анода на катод, число которых растет вследствие образования конусов на подошве анода. Это приводит к колебаниям температуры и снижению выхода по току в среднем на $1,5 \%$ [1].

Одно из основных воздействий угольной пены - увеличение электрического сопротивления электролита, которое может быть непосредственно связано с образованием конусов, исследовалось многими авторами. В работе Ветюкова [2] изучалось влияние углерода, взвешенного в электролите, на его удельное сопротивление при $1050{ }^{\circ} \mathrm{C}$. Электролит имел криолитовое отношение 2,35 с 8,5 мас. \% $\mathrm{Al}_{2} \mathrm{O}_{3}$. Угольную пену имитировали графитовые частицы, которые вводилась в сухую шихту из компонентов электролита. Крупность частиц изменялась от $\approx 0,7$ до 0,028 мм, количество было равно 1 и 3 мас. \% Результаты приведены в табл. 1 .

Как видно из табл. 1, расплавы, содержащие графитовые частицы обладают большим удельным сопротивлением по сравнению с безуглеродным электролитом, удельное сопротивление которого равно $\approx 0,490$ Ом·см, и относительное увеличение удельного сопротивления для самых мелких частиц достигает $\approx 300 \%$ при $3 \%$ углерода и $\approx 60 \%$ при $1 \%$ углерода.

Причиной увеличения удельного сопротивления авторы считают сокращение «живого» сечения электролита. Но фактическое уменьшение «живого» сечения электролита превышало расчетное, если рассматривать угольные частицы как непроводящие шары с соответствующими размерами. Этот факт объяснили тем, что в данных условиях на поверхности угольных частиц происходит образование карбида, который увеличивает диаметр частицы.

В работе [3] в лабораторных экспериментах установлено, что при пропускании одной и той же силы тока через ячейку при $960{ }^{\circ} \mathrm{C}$ падение напряжения U в электролите увеличивается с ростом концентрации С в нем угольных частиц (dU/dC $\approx 0,29 \mathrm{~B} /$ мас. \%). Это явно свидетельствует о возрастании электросопротивления электролита по мере добавления в него угольных частиц. Показано, что после расплавления электролита угольные частицы распределяются по всему его объему, но неравномерно. Основная часть концентрируется на поверхности электролита и 
Таблица 1. Зависимость удельного сопротивления электролита от крупности и концентрации угольных частиц

\begin{tabular}{|c|l|c|c|c|c|c|}
\hline $\begin{array}{c}\text { Количество } \\
\text { углерода, мас. \% }\end{array}$ & \multicolumn{1}{|c|}{$\begin{array}{c}\text { Средняя крупность } \\
\text { угольных частиц, мм }\end{array}$} & 0,725 & 0,310 & 0,152 & 0,080 & 0,028 \\
\hline \multirow{2}{*}{1} & $\begin{array}{l}\text { Удельное сопротивление, } \\
\text { Ом·см }\end{array}$ & 0,515 & 0,522 & 0,520 & 0,570 & 0,809 \\
\cline { 2 - 7 } & $\begin{array}{l}\text { Относительное увеличение } \\
\text { удельного сопротивления, \% }\end{array}$ & 4,5 & 5,9 & 5,5 & 15,6 & 64,4 \\
\hline 3 & $\begin{array}{l}\text { Удельное сопротивление, } \\
\text { Ом·см }\end{array}$ & 0,542 & 0,555 & 0,645 & 0,760 & 1,948 \\
\cline { 2 - 7 } & $\begin{array}{l}\text { Относительное увеличение } \\
\text { удельного сопротивления, \% }\end{array}$ & 11,5 & 14,2 & 32,7 & 56,4 & 301,0 \\
\hline
\end{tabular}

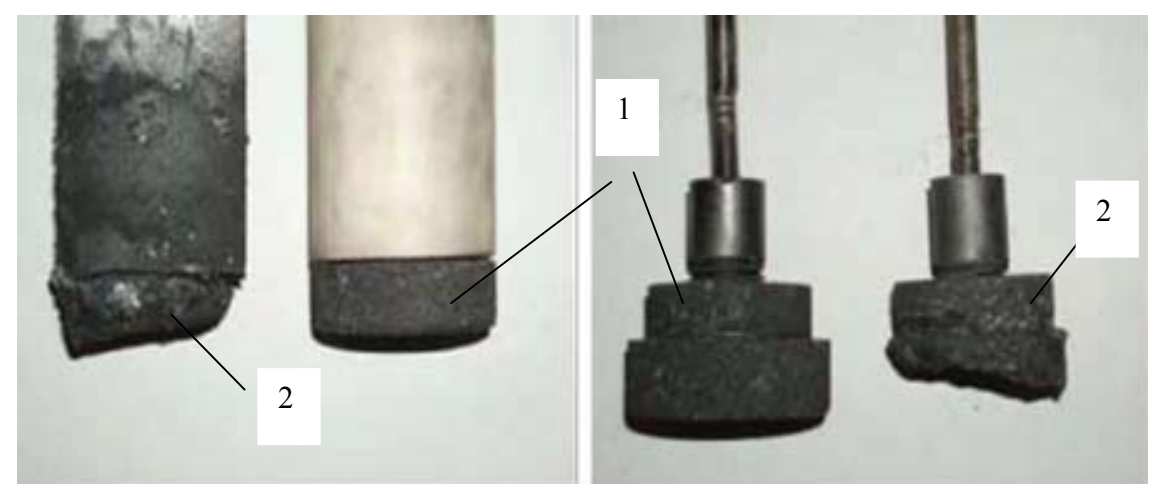

Рис. 1. Неравномерное срабатывание анодов в лабораторном электролизере, обусловленное угольными частицами под анодом при общем их содержании 8 мас. \%; 1 - новые аноды; 2 - аноды после эксперимента

под анодом. Угольные частицы, находящиеся под анодом, рассматриваются как оказывающие наиболее вредное воздействие. Кроме увеличения электросопротивления они обусловливают неравномерное распределение тока по подошве анода и, следовательно, неравномерное его срабатывание, как показано на рис. 1 .

В работе отмечается, что накопление угольных частиц под анодом может затруднять доступ глинозема к подошве анода, что, с одной стороны, увеличивает риск возникновения анодного эффекта, а с другой - приводит к неравномерному срабатыванию анода. Накопление пены под анодом может ингибировать «нормальные» анодные реакции и тем самым также инициировать образование неровностей на подошве анода из-за его неравномерного срабатывания.

Влияние угольных частиц на электросопротивление электролита в лабораторных и промышленных условиях изучено в работе [4]. Лабораторные эксперименты проводили при $980{ }^{\circ} \mathrm{C}$ в электролите состава, мас. \%: $\mathrm{Na}_{3} \mathrm{AlF}_{6}-80 ; \mathrm{AlF}_{3}-12 ; \mathrm{CaF}_{2}-5 ; \mathrm{Al}_{2} \mathrm{O}_{3}$ - 3. Для получения угольной пены в электролит вводили угольные частицы, получаемые измельчением кокса до среднего размера 1,9 мкм.

В опытах измеряли силу тока, проходящего радиально между двумя коаксиальными электродами при одном и том же напряжении 3,87 В. 
Было выполнено три серии опытов с содержанием угольных частиц в электролите 1,01; 0,16; 0,06 мас. \%. Результаты экспериментов и расчетов представлены в табл. 2.

Как видно, угольные частицы в электролите существенно увеличивают его электрическое сопротивление.

B экспериментах на промышленных электролизерах определяли падение напряжения U при ступенчатом уменьшении МПР на 4 мм, с выдержкой на каждой ступени по 10 мин. Были выбраны две группы электролизеров, одна с электролитом, очищенным от угольной пены, со средним содержанием углерода 0,07 мас. \%, другая - с запененным электролитом с содержанием углерода 0,11 мас. \%. Пробы на углерод брались примерно с середины слоя электролита. Обнаружено, что в электролизерах, содержащих большее количество угольной пены, при снижении МПР на 4 мм падение напряжения уменьшается на большую величину. Для электролизеров с очищенным от пены электролитом величина $\partial \mathrm{U} / \partial$ (МПР) составляет $\approx 47 \mathrm{MB} / \mathrm{MM}$, в то время как для электролизеров с запененным электролитом $-\approx 61 \mathrm{MB} / \mathrm{MM}$, что свидетельствует о большем (примерно на 30 \%) электросопротивлении, что может быть частично обусловлено угольной пеной.

Угольная пена как причина образования конусов. В промышленных условиях, по мнению авторов работ [5, 6], сразу после удаления старого анода в «лузе» начинает скапливаться угольная пена (рис. 2), образуя на части поверхности электролита слой толщиной до 50 мм, который может затвердевать еще до установки нового анода, поскольку теряет с излучением на $20 \%$ больше тепла, чем чистая поверхность электролита. Помещение холодного анода на охлажденную пену приводит к образованию на части подошвы анода твердого слоя толщиной 40-55 мм, что соизмеримо с МПР.

Таблица 2. Условия и результаты экспериментов

\begin{tabular}{|l|c|c|c|}
\hline \multicolumn{1}{|c|}{ Содержание угольных частиц, \% } & 1,01 & 0,16 & 0,06 \\
\hline Сила тока, А & 17,4 & 20,8 & 21,8 \\
\hline Напряжение на ячейке, В & 3,87 & 3,87 & 3,87 \\
\hline Сопротивление электролита, Ом & 0,0499 & 0,0335 & 0,0297 \\
\hline Относительное удельное сопротивление электролита, \% & 168 & 113 & 100 \\
\hline
\end{tabular}

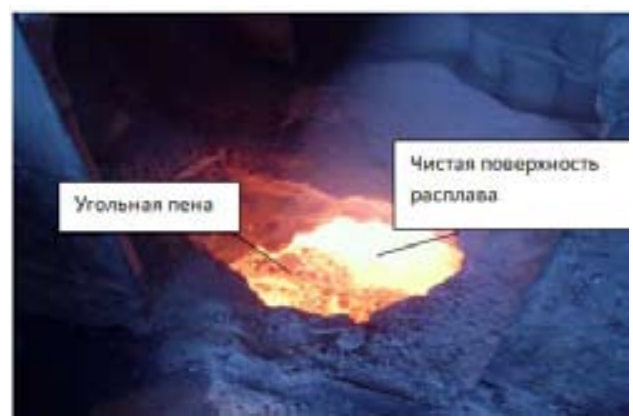

Рис. 2. Угольная пена в «лузе» после удаление анодного огарка [7]

$$
-597 \text { - }
$$


Этот слой плавится намного медленнее, чем намерзший слой чистого электролита без пены. Как следствие, возникает конус. На рис. 3 показан усеченный конус на подошве анода спустя четверо суток после его установки. Как видно, высота его составляет 8 см, что соответствует примерно четырем суткам работы остальной части подошвы анода.

В работе [7] установлено, что наибольшее количество конусов образуется на торцевых анодах в местах подошвы, близких к бортам электролизеров, где перегрев наименьший, а количество пены, как показал анализ намерзшего электролита, в 2-3 раза больше, чем в других частях электролизера.

Обеднение электролита по глинозему как причина образования конусов. Альтернативная точка зрения на причину образования конусов высказывается в работе [8]. Авторы обнаружили корреляцию между периодами питания электролизеров и силой тока, проходящей через индивидуальный анод, через 5 ч после установки нового анода и уменьшения МПР до целевого значения в соответствии с рис. 4.

Была выдвинута гипотеза, что локальное уменьшение концентрации глинозема у некоторых анодов должно вызвать уменьшение силы тока, проходящей через эти аноды. В то же время повышение концентрации глинозема должно привести к росту силы тока. Было обнаружено, что на подошве анодов, у которых наблюдается корреляция между периодами питания

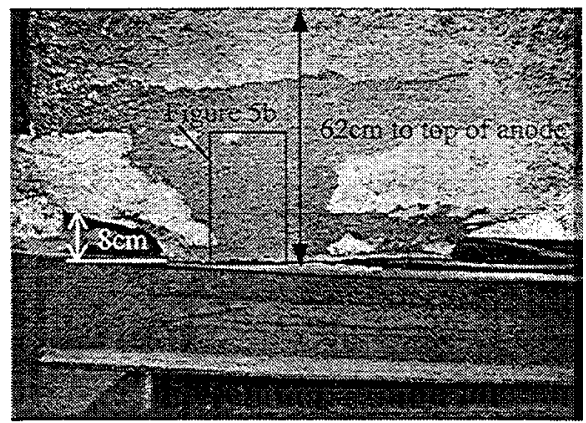

Рис. 3. Усеченный конус на подошве анода после четырех дней работы

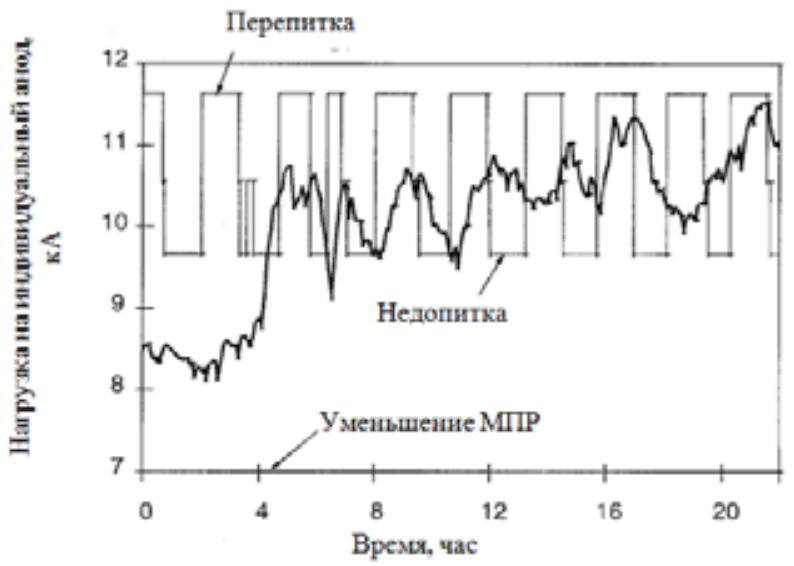

Рис. 4. Нагрузка на индивидуальный анод и цикл питания электролизеров глиноземом 


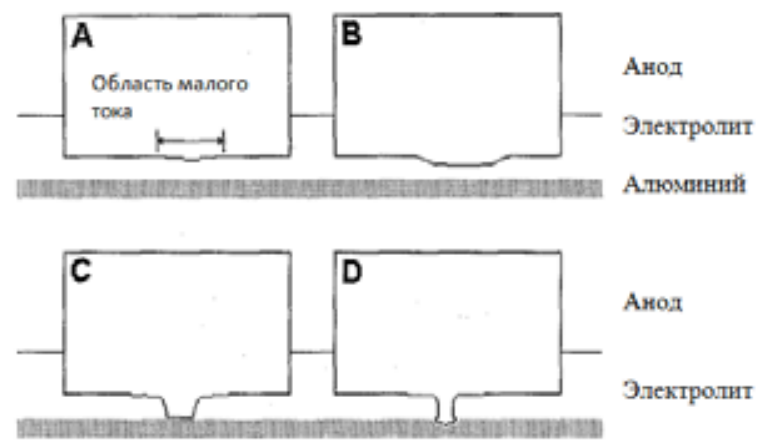

Рис. 5. Развитие конуса, спровоцированное уменьшением концентрации глинозема под частью подошвы анода

и силой тока, возникают конусы, состоящие из того же самого материала, что и анод. Авторы предположили, что локальное изменение концентрации глинозема может иметь место также в пределах одного анода, что и провоцирует образование конусов.

Уменьшение концентрации глинозема в некоторой области подошвы анода приводит к уменьшению силы тока, и, как следствие, расход анода становится меньше, чем в соседних областях, где концентрация глинозема больше. Когда локальное МПР в этой области становится меньше, это еще больше затрудняет к ней поступление глинозема и конус начинает расти. Процесс развивается по типу положительной обратной связи вплоть до замыкания конуса на металл (рис. 5).

Анализируя опыт повышения силы тока на заводах компании Hydro Aluminium, Мокснэс, Квандэ и Солхейм [9] отмечают, что существует тенденция повышения частоты образования конусов на подошве анодов с увеличением силы тока. Конусы могут быть вызваны различными причинами, но одна из главных - неравномерное распределение глинозема в электролите, обусловленное уменьшением МПР и объема электролита при повышении силы тока. Вторая главная причина связана с угольной пеной которая увеличивает электрическое сопротивление электролита, в результате чего уменьшается сила тока на участке подошвы анода, который экранируется угольной пеной и в этом месте анод срабатывается меньше. Влияние пены усиливается при снижении МПР. Повышение силы тока приводит к росту образования пены, что еще сильнее обостряет проблему конусов.

Растворенный в электролите углерод как причина образования конусов. Еще одна гипотеза о причине образования конусов, её можно назвать электрохимической, связана с окислением углерода на аноде. Расплавы алюминиевого электролизера контактируют с материалами, содержащими углерод: подиной электролизера, анодными блоками, угольной пеной, карбидом алюминия. В исследованиях Хренковой с соавторами [10], Удэгарда, Стэртенанда и Тонстэда [11] показано, что при температурах, близких к температуре электролиза, углерод и карбид алюминия растворяются в криолите и криолитоглиноземных расплавах по реакциям:

$$
\begin{aligned}
& 3 \mathrm{C}(\mathrm{T})+12 \mathrm{Na}(\mathrm{p})+ 4 \mathrm{AlF}_{3}(\mathrm{p})=\mathrm{Al}_{4} \mathrm{C}_{3}(\mathrm{p})+12 \mathrm{NaF}(\mathrm{p}) \Delta \mathrm{G}_{1300 \mathrm{~K}}^{\mathrm{o}}=-762 \kappa \text { К }, \\
& \mathrm{C}+4 \mathrm{Na}+3 \mathrm{AlF}_{3}=\mathrm{Na}_{3} \mathrm{Al}_{3} \mathrm{CF}_{8}+\mathrm{NaF} \Delta \mathrm{G}_{1300 \mathrm{~K}}^{\mathrm{o}}=-310 \kappa \text { кж, } \\
&-599-
\end{aligned}
$$




$$
\begin{aligned}
& 2 \mathrm{C}+3 \mathrm{NaAlF}_{4}=\mathrm{Na}_{3} \mathrm{Al}_{3} \mathrm{CF}_{8}+\mathrm{CF}_{4} \Delta \mathrm{G}_{1300 \mathrm{~K}}^{\mathrm{o}}=893 \kappa \text { к }, \\
& \mathrm{Al}_{4} \mathrm{C}_{3}+9 \mathrm{NaF}+5 \mathrm{AlF}_{3}=3 \mathrm{Na}_{3} \mathrm{Al}_{3} \mathrm{CF}_{8}(\mathrm{p}) \Delta \mathrm{G}^{\mathrm{o}}{ }_{1300 \mathrm{~K}}=-169,5 \kappa \text { кж }
\end{aligned}
$$

до содержания от 0,7 до 2,2 мас. \%.

Очевидно, что образующийся по реакции (1) карбид алюминия может далее вступать в реакцию с компонентами электролита с образованием соединения $\mathrm{Na}_{3} \mathrm{Al}_{3} \mathrm{CF}_{8}$, которое может рассматриваться как окончательный продукт растворения углерода и карбида алюминия в электролите.

Растворимость карбида алюминия в электролите была измерена во многих работах. В [11] установлено, что растворимость увеличивается с уменьшением криолитового отношения, температуры, концентрации глинозема и фторида кальция.

Соединение $\mathrm{Na}_{3} \mathrm{Al}_{3} \mathrm{CF}_{8}$ может диссоциировать в расплаве на ионы $\mathrm{Na}^{+}$и $\mathrm{Al}_{3} \mathrm{CF}_{8}{ }^{3-}$. Степень окисления углерода в анионе равна -4 , поэтому он вполне может окисляться на аноде с образованием элементарного углерода. Реакция окисления согласно [11] имеет вид

$$
\mathrm{Al}_{3} \mathrm{CF}_{8}^{3-}+\mathrm{F}-=\mathrm{C}+3 \mathrm{AlF}_{3}+4 \mathrm{e}
$$

и получающийся углерод образует твердый осадок на аноде. Причем для осуществления этой реакции потенциал анода нужно сдвинуть в положительную сторону на величину существенно меньшую, чем требуется для выделения $\mathrm{CO}_{2}$.

\section{Возможные мероприятия}

\section{по снижению технологических нарушений в аноде}

Согласно [5] к уменьшению частоты образования конусов могут привести следующие действия:

1) установка нового анода на 2,5 см выше позиции старого анода;

2) удаление укрывного материала как источника угольной пены;

3) питание электролизеров первичным глиноземом;

4) увеличение напряжения на электролизере.

Действительно, выполнение этих мероприятий в среднем приводит к снижению частоты образования конусов (табл. 3).

Кроме того, отмечается в работе [6], частота образования конусов уменьшается при увеличении перегрева электролита, причем необходима специальная программа управления перегревом. Были испытаны две программы. Согласно первой программе после установки нового

Таблица 3. Результаты мероприятий, проведенных для снижения количества конусов

\begin{tabular}{|c|c|c|}
\hline \multirow{2}{*}{ Мероприятие } & Опытные электролизеры & Электролизеры-свидетели \\
\cline { 2 - 3 } & \multicolumn{2}{|c|}{ \% конусов на установленный анод } \\
\hline 1 & 9 & 16 \\
\hline 2 & - & - \\
\hline 3 & 8 & 13 \\
\hline 4 & 13 & 26 \\
\hline
\end{tabular}


анода напряжение на электролизере поднималось на 120 мВ с выдержкой в течение 2 ч. Затем напряжение ступенчато снижалось до номинального значения в соответствии с данными, приведенными в табл. 4.

За это время в электролизер поступало 62,56 кВт·ч добавочной энергии - только $21 \%$ от энергии (300 кВт·ч), необходимой для нагревания анода до рабочей температуры. В результате при установке нового анода перегрев сначала в течение 3 ч уменьшался примерно в 2 раза. Затем начинал увеличиваться, причем увеличение перегрева до прежнего уровня занимало до 15 ч. Работа по первой программе не привела к снижению частоты образования конусов. Авторы [6] утверждают, что на заводе Voerde малый перегрев, имеющий место после установки анода, в сочетании с большим количеством угольной пены - основная причина высокой частоты образования конусов.

Чтобы снизить вероятность образования конусов, была изменена программа управления перегревом (табл. 5). Количество добавочной энергии было увеличено до $50 \%$ от требуемого для нагревания анода до рабочей температуры. Напряжение поднимали на 70 мВ за 8 ч до предполагаемого времени установки нового анода (вторая программа).

В этом случае перегрев увеличивался до установки анода примерно на 60 \% больше, чем при использовании первой программы. При установке нового анода перегрев снижался, но только до уровня, который был до начала подъема напряжения.

Результаты работы по второй программе были положительными: выход по току увеличился на $0,8 \%$, среднее число конусов, возникающих за месяц на одном электролизере, снизилось на $60 \%$.

Таким образом, для снижения частоты образования конусов необходимо поддерживать постоянный перегрев электролита, по крайней мере, не ниже $10{ }^{\circ} \mathrm{C}$ и уменьшить количество

Таблица 4. Изменение напряжения во времени после установки нового анода (первая программа)

\begin{tabular}{|c|c|c|}
\hline Добавочное напряжение, мВ & Время выдержки, мин & Общее время, ч \\
\hline 120 & 120 & 2,0 \\
\hline 78 & 40 & 2,7 \\
\hline 58 & 40 & 3,3 \\
\hline 38 & 40 & 4,0 \\
\hline 18 & 40 & 4,7 \\
\hline 0 & - & - \\
\hline
\end{tabular}

Таблица 5. Изменение напряжения во времени по второй программе

\begin{tabular}{|c|c|c|}
\hline Добавочное напряжение, мВ & Время выдержки, мин & Общее время, ч \\
\hline 70 & 500 & 8,3 \\
\hline 28 & 440 & 15,7 \\
\hline 14 & 440 & 23 \\
\hline 0 & - & - \\
\hline
\end{tabular}


углерода, поступающего от различных источников в электролит и образующего угольную пену.

\section{Механические разрушения анодного блока}

Аноды в алюминиевых электролизерах работают в суровых термических и химических условиях. В первые дни после установки, когда анодные блоки подвергаются сильным термическим напряжениям под действием градиентов температуры (термический удар), в них могут развиваться трещины, распространяющиеся в различных направлениях и вызывающие нарушение работы анодов и даже их разрушение, как это показано на рис. 6 [12].

Типичные конфигурации трещин, возникающих в аноде при термическом ударе, приведены на рис. 7 [13].

Поведение анодного блока при термическом ударе зависит от таких свойств, как теплопроводность; коэффициент теплового расширения; модуль упругости, модуль Вейбулла или параметр формы распределения, характеризующий распределение прочности хрупкого материала по величине и хорошо описывающий статистически поведение анодов при образовании трещин на основе концепции слабого звена; энергия разрушения. Все эти свойства зависят от качества сырья и от условий изготовления анодов. На поведение анода также существенно влияют условия электролиза. Количественно поведение анода при термическом ударе предложено характеризовать величиной сопротивления термическому удару TSR, определяемой

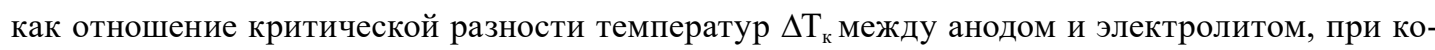
торой следует ожидать образования трещин, к реальной разности температур $\Delta \mathrm{T}$, и включает характеристики материала анода, геометрические размеры и модуль Вейбула, для нахождения которого требуется статистическая информация по разрушению анодных блоков конкретного поставщика и по влиянию режима установки анода в электролизер [14].

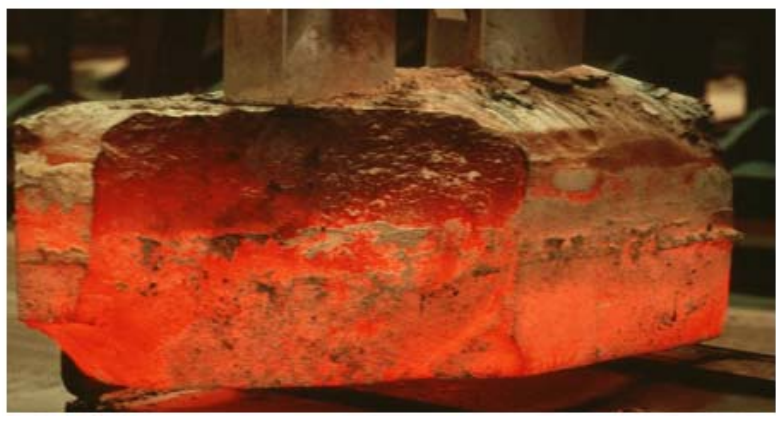

Рис. 6. Разрушение анодного блока при образовании трещины

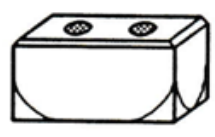

A

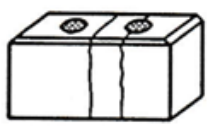

B

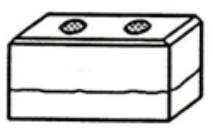

C

Рис. 7. Схема анодных блоков с трещинами: А - угловыми; В - вертикальными; С-горизонтальными 


$$
T S R=\frac{\Delta T_{k}}{\Delta T}=\sqrt{\frac{2 G \cdot\left(\frac{V_{k}}{V_{A}}\right)^{\frac{1}{m}}}{\pi \cdot a \cdot E} \frac{2 \lambda \cdot(1-v)}{\alpha \cdot \mathrm{L} \cdot \mathrm{h} \cdot \mathrm{Y} \cdot \Delta T}},
$$

где $\alpha$ - температурный коэффициент линейного расширения, $\mathrm{K}^{-1} ; \mathrm{E}$ - статический модуль упру-

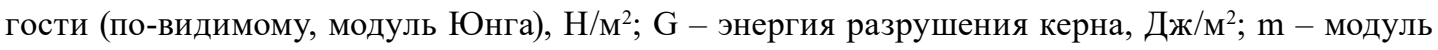
Вейбула; $a$ - размер трещины, м; $\lambda$ - теплопроводность, Вт/м·K; $v$ - коэффициент Пуассона; L характерная длина анода, м, равная отношению объема, подвергнутого термическому удару, к площади сечения распространения тепловой волны; $\mathrm{h}$ - коэффициент теплообмена, Вт/ $\mathrm{m}^{2} \cdot \mathrm{K}$; $\mathrm{Y}$ - безразмерная величина, зависящая от геометрии и способа установки анода; $\Delta \mathrm{T}$ - разность между температурами электролита и анода до его установки, $\mathrm{K} ; \mathrm{V}_{\mathrm{k}}-$ объем керна, находящийся под действием термических напряжений, $\mathrm{M}^{3} ; \mathrm{V}_{\mathrm{A}}$ - объем, находящийся под действием термических напряжений в целом аноде, $\mathrm{m}^{3}$.

Если TSR $>1$, разрушение анода при термическом ударе маловероятно, если TSR $<1$, при термическом ударе следует ожидать разрушение анода.

По величине TSR можно оценивать стойкость анода к термическому удару, однако, для этого необходима статистическая информация. Поэтому делаются попытки выразить TSR через параметры, которые определяются по стандартным методикам, например, в более простом виде

$$
\operatorname{TSR}=\frac{\lambda \cdot \sigma_{\text {uз2. }}}{\alpha \cdot E}
$$

где $\alpha$ - температурный коэффициент линейного расширения, $\mathrm{K}^{-1} ; \lambda$ - теплопроводность, Вт/м·К; $\sigma_{\text {изг }}-$ прочность на изгиб, МПа; Е - модуль Юнга, ГПа.

Однако, как показано в [14], этот показатель не отражает реальную стойкость анодного блока к термическому удару.

В работе [15] методом конечных элементов проведено математическое моделирование распределения температуры и механических напряжений в анодных блоках через 1,5 и 240 ч после их установки в электролизер. Рассматриваются аноды двух размеров: 152 х 108 х 51 см - А и 108 х 76 х 51 см - В. Показано, что через 1,5 ч распределение температуры по верху и подошве анодов примерно равномерное (градиент температуры в горизонтальном направлении мал) для анодов обоих размеров и становится еще равномернее через 240 ч. Однако по вертикали разность температур между поверхностью и подошвой очень большая: через 1,5 ч при температуре электролита $950{ }^{\circ} \mathrm{C}$ она составляет в среднем $850{ }^{\circ} \mathrm{C}$, а через 240 ч $-\approx 180{ }^{\circ} \mathrm{C}$. Стационарное распределение температуры достигается примерно через 168 ч.

Моделирование механических напряжений, обусловленных градиентами температуры (термических напряжений), показало, что напряжения в различных направлениях для анодов А и В очень отличаются, особенно через 240 ч в соответствии с табл. 6.

Спустя 1,5 ч после установки анода в его нижней части возникают максимальные касательные напряжения 3,5 и 2,8 МПа. По величине они меньше, чем предел прочности на сдвиг для углеродистых анодов, который оценивается в 3,7 МПа, однако их высокая концентрация может приводить к сколу нижних углов анодов.

$$
-603-
$$


Таблица 6. Максимальные значения механических напряжений в теле анодов через различное время после установки, МПа

\begin{tabular}{|l|c|c|c|c|}
\hline \multirow{2}{*}{ Направление напряжения } & \multicolumn{2}{|c|}{1,5 ч } & \multicolumn{2}{c|}{240 ч } \\
\cline { 2 - 5 } & Анод А & Анод В & Анод А & Анод В \\
\hline Касательные напряжения & 3,5 & 2,8 & 4,5 & 0,8 \\
\hline Нормальные напряжения & 4,2 & 4,0 & 9,1 & 0,9 \\
\hline Растягивающие напряжения по оси $x$ & 3,8 & 4,0 & 6,0 & 0,5 \\
\hline Растягивающие напряжения по оси $y$ & 4,2 & 3,3 & 8,5 & 0,4 \\
\hline Растягивающие напряжения по оси $z$ & 1,6 & 1,7 & 0,6 & 0,3 \\
\hline
\end{tabular}

Максимальные нормальные напряжения получились также меньше, чем предел прочности на разрыв материала анода ( $\approx 5$ МПа).

Через 240 ч после смены анодов максимальные растягивающие напряжения возникают в горизонтальном направлении (по осям $x$ и $y$ ) в верхней части анода А, но не в аноде В. Большие растягивающие напряжения в направлении оси $у$ могут вызвать вертикальные трещины в верхней части анодных блоков через относительно длительное время работы анода.

Отметим, что математическое моделирование позволило определить деформацию анодных блоков через 1,5 ч и 240 ч после их установки в электролизер. Показано, что через 1,5 ч очень деформируется нижняя часть блока анодов А и В, так что исходная форма в виде прямоугольного параллелепипеда искажается. Через 240 ч аноды несколько увеличиваются в размерах, но практически принимают свою первоначальную форму. Величины деформаций в [15] не приводятся.

Одной из возможностей увеличения сопротивления анода к термическому удару является использование анодных блоков с пазами. В работе [16] показано, что количество трещин в огарках, которое определяли при замене анодов, снизилось примерно в 4 раза, когда стали применять аноды с поперечными пазами. Это связано, как указывают авторы, с изменением геометрии блоков.

В [17] было математически смоделировано в двумерном пространстве первичное и вторичное распределение тока по аноду. На основании последнего была создана модель изменения формы анода после его установки.

Расчет в пределах допущений, принятых в работе, показал, что первичное и вторичное распределения тока на подошве анода различаются не очень, но на боковых поверхностях и вблизи поверхности электролита различие существенное. Как при первичном, так и при вторичном распределении плотность тока всегда выше, после того как анод приобретает постоянную форму прямоугольного параллелепипеда с округлыми ребрами. Такую форму анод приобретает спустя 6-8,6 сут после установки в зависимости от расстояния до соседнего анода и настыли: чем меньше расстояние, тем быстрее анод приобретает постоянную форму. В среднем через боковые стороны анода течет около $15 \%$ от общего тока через анод, причем плотность тока падает на 11-37 \% в зависимости от геометрии поверхности, от номинальной на подошве анода до минимальной у поверхности электролита. Чем сильнее скруглены углы и ребра, тем больше плотность тока у поверхности электролита. В работе высказано предложение изготавливать

$$
-604-
$$


анодные блоки сразу имеющими форму, которую они приобретают после 6-9 сут работы. В этом случае распределение плотности тока не будет меняться со временем, а сход пузырьков газа будет облегчен.

\section{Заключение}

На основании проведенного анализа российских и зарубежных источников можно выделить три основные гипотезы о причинах образования «конусов» на подошве анода:

1) электрохимическая;

2) механическая;

3) концентрационная.

Согласно первой конус образуется из растворенного в электролите углерода по реакции (5). На концентрацию углерода в электролите влияет выход угольной пены и качество анода. При низком качестве анода возникает неравномерность токораспределения. Эта гипотеза объясняет появление конусов, состоящих из двух слоев. Внутренний слой имеет тот же состав, что и тело анода. Второй слой состоит из электрохимически осажденного углерода.

Согласно второй гипотезе конус является следствием неравномерного срабатывания анода в процессе электролиза, что также связано с неравномерностью токораспределения. Эта гипотеза объясняет образование конусов, имеющих тот же состав, что и тело анода.

Согласно третьей гипотезе причиной образования конусов выступает низкая концентрация глинозема в электролите.

Еще одна гипотеза, которой, по мнению авторов, уделено недостаточно внимания в зарубежных и российских работах, электрофоретическая, согласно которой частицы углерода переносятся к поверхности анода под действием сил, вызванных градиентом электрического потенциала. Эта и другие гипотезы требуют экспериментального подтверждения.

\section{Список литературы}

[1] Barry Sadler and Barry Welch. Reducing carbon dust? - needs and possible directions, Ninth Australasian aluminium smelting technology conference and workshops, Light Metals, 2007, 1-14.

[2] Ветюков М.M., Чувиляев Р.Г. Поведение угольной «пены» при электролизе криолитглиноземных расплавов. Известия вузов. Цветная металлургия, 1964, 6, 74-81. [Vetyukov M.M., Chuvilyaev R.G. Behavior of carbon "foam" in the electrolysis of cryolite-alumina melts. Izvestiya usov. Tsvetnaya metallurgya, 1964, 6, 74-81. (in Russian)]

[3] Stanislaw Pietrzyk and Jomar Thonstad. Influence of carbon dust in the electrolyte on aluminium electrolysis parameters, ICSOBA Proceedings 2015, 659-666.

[4] L. Bugnion and J.-C. Fischer. Carbon dust in electrolysis pots - effect on the electrical resistivity of cryolite bath, Aluminium, 2016, 1-2, 44-47.

[5] Bernd Rolofs and Neal Wai-Poi. The Effect of Anode Spike Formation on Operational Performance, Light Metals, 2000, 189-193.

[6] Neal Wai-Poi and Bernd Rolofs. Impact of energy management and superheat on anode spike formation, Light Metals, 2001, 535-540.

[7] Halldor Gudmundsson. Anode dusting from a potroom perspective at Nordural and correlation with anode properties, Light Metals, 2011, 471-476. 
[8] Ketil A. Rye, Margit Konigsson and Ingar Solberg. Current redistribution among individual anode carbons in a Hall-Heroult prebake cell at low alumina concentrations, Light Metals, 1998, 241246.

[9] Bjørn Moxnes, Halvor Kvande and Asbjørn Solheim. Experience and challenges with amperage increase in hydro aluminium potlines, Light Metalls, 2007, 263-268.

[10] Chrencova V., Danek V., Sikny A., Koniar M., Stas M. Dissolution of cabornand A14C3 incryolite, Eleventh international Aluminium symposium, Trondheim - Bergen - Trondheim, Noway, 2001, 271-279.

[11] Udegärd R., Stertenand Ä., Thonstad J. On the solubility of aluminium carbide in cryolitic melts - influence on cell performance, Light Metals, 1987, 295-302.

[12] Raymond C. Perruchoud, Markus W. Meier and Werner K. Fischer. Survey on worldwide prebaked anode quality, Light Metals, 2004, 573-578.

[13] Markus W. Meier, Werner K. Fischer, Raymond C. Perruchoud, Ludwig J. Gauckler. Thermal shock of anodes - a solved problem? Light Metals, 1994, 685-694.

[14] Абрамович Р.Т., Шайдулин Е.Р., Храменко С.А., Гурьев Н.Н. Экспериментальная оценка термостойкости анодных блоков, Сборник докладов ХІІІ Международной конференции «Алюминий Сибири - 2007», 2007, 312-316 [Abramovich R.T., Shaydulin E.R., Hramenko S.A., Guryev N.N. An experimental evaluation of the thermal stability of anode blocks, Collection of reports of the XIII International Conference "Aluminum of Siberia 2007”, 2007, 312-316. (in Russian)]

[15] Tu-Lung Weng, Michael B. Hsu. Temperature and stresses in carbon anodes in an aluminum reduction cell, Light Metalls, 1984, 977-987.

[16] Handerson Penna Dias and Ronaldo Raposode Moura. The use of transversal slot anodes at albras smelter, Light Metalls, 2005, 341-344.

[17] Zorict J., Rousar I. and Thonstad J. Mathematical modeling of current distribution and anode shape in industrial aluminium cells with prebaked anodes, Light Metals, 1997, 449-456. 